\title{
A common soil temperature threshold for the upper limit of alpine grasslands in European mountains
}

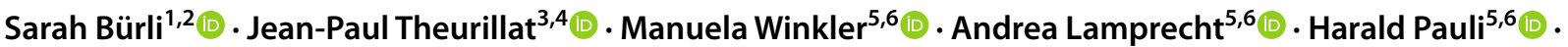

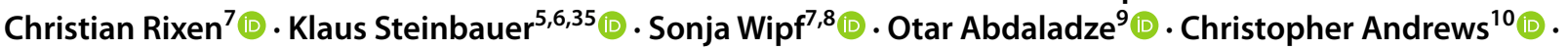 \\ Peter Barančok ${ }^{11}$ (1) . José Luis Benito-Alonso ${ }^{12}$ (D) . Maria Rosa Fernández Calzado ${ }^{13}$ (1) - Maria Laura Carranza ${ }^{14}$ (i) \\ Jan Dick ${ }^{10}$ - Brigitta Erschbamer ${ }^{15}$ - Dany Ghosn ${ }^{16}$ - Khatuna Gigauri $^{17}$ (D) George Kazakis ${ }^{16} \cdot$ Martin Mallaun $^{18}$.

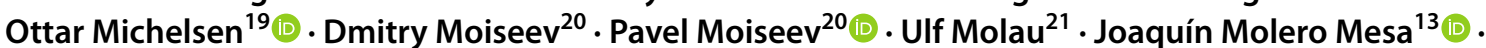 \\ Umberto Morra di Cella ${ }^{22}$ (1) Imran Nadeem ${ }^{23}$ (1) $\cdot$ Laszlo Nagy $^{24} \cdot$ Lena Nicklas $^{15}$ (1) $\cdot$ Andrej Palaj ${ }^{11}$ (D)

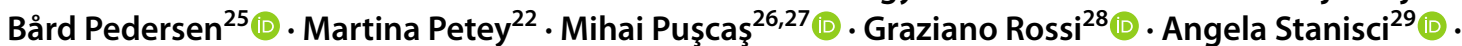 \\ Marcello Tomaselli ${ }^{30}\left({ }^{10} \cdot\right.$ Peter Unterluggauer ${ }^{31} \cdot$ Tudor-Mihai Ursu $^{32}(1) \cdot$ Luis Villar $^{33} \cdot$ Pascal Vittoz $^{34}(1)$
}

Received: 16 October 2020 / Accepted: 15 February 2021 / Published online: 4 March 2021

(c) The Author(s) 2021

\begin{abstract}
While climatic research about treeline has a long history, the climatic conditions corresponding to the upper limit of closed alpine grasslands remain poorly understood. Here, we propose a climatic definition for this limit, the 'grassline', in analogy to the treeline, which is based on the growing season length and the soil temperature. Eighty-seven mountain summits across ten European mountain ranges, covering three biomes (boreal, temperate, Mediterranean), were inventoried as part of the GLORIA project. Vascular plant cover was estimated visually in 326 plots of $1 \times 1 \mathrm{~m}$. Soil temperatures were measured in situ for 2-7 years, from which the length of the growing season and mean temperature were derived. The climatic conditions corresponding to $40 \%$ plant cover were defined as the thresholds for alpine grassland. Closed vegetation was present in locations with a mean growing season soil temperature warmer than $4.9^{\circ} \mathrm{C}$, or a minimal growing season length of 85 days, with the growing season defined as encompassing days with daily mean $\geq 1{ }^{\circ} \mathrm{C}$. Hence, the upper limit of closed grasslands was associated with a mean soil temperature close to that previously observed at the treeline, and in accordance with physiological thresholds to growth in vascular plants. In contrast to trees, whose canopy temperature is coupled with air temperature, small-stature alpine plants benefit from the soil warmed by solar radiation and consequently, they can grow at higher elevations. Since substrate stability is necessary for grasslands to occur at their climatic limit, the grassline rarely appears as a distinct linear feature.
\end{abstract}

Keywords Alpine life zone · GLORIA · Growing season · Plant-Climate interactions · Soil temperature · Vascular plants

\section{Introduction}

The geographical distribution of species is strongly related to their dispersal mode, habitat suitability, and biotic interactions (Lortie et al. 2004). Among the factors controlling habitat suitability, climate is one of the most important, at both the global and the local scales (Walter and Breckle 1985). In mountainous areas, with steep temperature gradients that correlate with elevation, the relationship between climate

Pascal Vittoz

pascal.vittoz@unil.ch

Extended author information available on the last page of the article and species distribution is particularly strong (Körner 2003; Leuschner and Ellenberg 2017).

Studying abiotic thresholds to plant growth along temperature gradients, such as those along elevation, are useful for ascertaining distribution limits defined by physiological limits of plants (Körner and Paulsen 2004; Dvorský et al. 2017). The ability of species to grow or reproduce can change abruptly along abiotic gradients (Crawford 2008). Such thresholds are sometimes visible as sharp boundaries on mountain slopes, for example, in the case of the treeline (see Brockmann-Jerosch 1919; Körner 2012). Körner and Paulsen (2004) concluded that a mean growing season soil temperature (at $10 \mathrm{~cm}$ depth) of $6.7^{\circ} \mathrm{C}$ coincided with 
the position of the subalpine-alpine treelines around the world. Tree growth at the treeline is not limited by carbon acquisition, but by tissue growth (Hoch and Körner 2012). Observations and experiments confirmed that xylogenesis is not possible with air temperatures below $3-4{ }^{\circ} \mathrm{C}$ (Rossi et al. 2008), and root growth is strongly reduced when soil temperature drops below $5{ }^{\circ} \mathrm{C}$ (Häsler et al. 1999; Schenker et al. 2014), with minimum soil temperature for root growth in trees measured at $2.3{ }^{\circ} \mathrm{C}$ (Sorbus aucuparia; Schenker et al. 2014). As growth limitation of trees above the treeline appears to be related to physiological constraints, a similar physiological threshold may be assumed for all vascular plant species, regardless of their growth form. Körner and Paulsen (2004) suggested that alpine plants face similar thermal limitations as trees, but reach limiting temperatures at higher elevations due to warmer daytime conditions closer to the ground during sunny days. For example, Scherrer and Körner (2010) measured surface temperatures on average $4.7 \mathrm{~K}$ warmer than air temperature (at $2 \mathrm{~m}$ ) in south-southeast-exposed alpine grasslands in the Swiss Alps (2430 m a.s.l.) between 12 and $18 \mathrm{~h}$ during sunny days.

Not only temperature, but also the length of the growing season is an important limitation to vascular plant growth. Tree growth in the northern hemisphere (from 28 to $68^{\circ}$ latitude) has been found to be possible at a mean growing season length of $126 \pm 18$ days, with a minimum length of 91 days (Körner and Paulsen 2004). For alpine plants, Körner (2003) reported that 42-49 days without snow are necessary for a vascular plant to survive, and Theurillat et al. (1998) noted that, in the Alps, the upper limit of closed grasslands corresponds to a growing season length of around 50 days (with daily means $\geq 5^{\circ} \mathrm{C}$ ). However, these values are based on regional observations. At larger scales, values for the length of the growing season, and the mean temperature during the growing season at the upper limit of grasslands, have not been reported.

The upper limit of the closed alpine vegetation is generally considered as the alpine-nival ecocline (Reisigl and Pitschmann 1958; Gottfried et al. 2011). Although often patchy and thus less visible in the landscape than the treeline, this limit, hereafter referred to as grassline, is analogous to the treeline. If limited by temperature or growing season length, and assuming suitable substrates for plant growth are present, this grassline would be expected to move upslope in a warming climate, thus fundamentally changing the appearance of high-elevation mountain ranges through a greening of the summits (Rogora et al. 2018).

To date, mean soil temperatures of $9.6 \pm 2.7^{\circ} \mathrm{C}$ and growing season lengths of $164 \pm 33$ days have been reported for the middle of the alpine belt (200-250 m above climatic treeline) for a wide range of latitudes in western and central Europe (Körner et al. 2003). However, being limited to the mid-alpine belt rather than the grassline, the hypothesis of a climatic threshold to closed alpine vegetation remains open. To assess if there is such a climatic set point for a grassline, we used soil temperature data and vegetation monitoring plots on 87 mountain summits across Europe. Based on previous studies, we hypothesized that the position of the grassline was related to (1) a mean soil temperature in the growing season similar to that of the treeline, i.e. around $5-7{ }^{\circ} \mathrm{C}$, and (2) a growing season length that would fall between the minimum required for vascular plants (42-49 days) and the minimum length observed for the treeline (91 days).

\section{Materials and methods}

\section{Data collection}

Vegetation and soil temperature data were derived from permanent plots established within the Global Observation Research Initiative in Alpine Environments (GLORIA, www.gloria.ac.at) network, initiated in 2001 to monitor climate warming impacts on mountain vegetation (Pauli et al. 2015). Each region belonging to the network consists of (usually) four summits along a temperature gradient, ideally from the treeline ecotone to the subnival zone (or to the highest summit of the region). Monitoring plots on these summits were set up between 2001 and 2006, and resurveyed at ca. 7-year intervals since. Regions with available soil temperature data for at least two complete growing seasons resulted in including 87 mountain summits, from 22 European mountain regions, and ten different mountain ranges (Table 1 and Fig. 1). Each region was assigned to a 'biome', following Winkler et al. (2016): boreal in Northern Europe, temperate in Central Europe, and Mediterranean in Southern Europe (Table 1).

On each summit, a quadrat cluster of $3 \mathrm{~m} \times 3 \mathrm{~m}$ (hereafter cluster) was established $5 \mathrm{~m}$ below the peak in each of the four cardinal directions. In four cases the slopes were too steep for establishing clusters, leading to a total of 344 clusters out of 348 potential locations for 87 summits. In the four $1 \mathrm{~m} \times 1 \mathrm{~m}$ corner plots of each cluster, the cover of each vascular plant species was estimated visually to the nearest $0.01 \%$, together with the percentage surface cover of vascular plants, bryophytes, lichens, solid rock, scree, bare soil and litter. For regions with two or more surveys, the second one (mostly conducted in 2008) was used in the analyses, or the one that came closest to the period with temperature time series data (Table 1).

Temperature data were derived from temperature loggers (Onset TidbiT and GeoPrecision M-Log5W) buried at $10 \mathrm{~cm}$ soil depth in the centre of each $3 \mathrm{~m} \times 3 \mathrm{~m}$ cluster, assuming that the measured temperatures reflect the thermal conditions in the four neighbouring vegetation plots 
Table 1 List of the 22 incorporated regions

\begin{tabular}{|c|c|c|c|c|c|}
\hline Region name & Code & Survey year & Temperature data & Biome & Summit elevation [m. a.s.1.] \\
\hline 1. Polar Urals (Russia) & RU-PUR & 2008 & $2002-07$ & Boreal & $300,417,641,839$ \\
\hline 2. South Urals (Russia) & RU-SUR & 2008 & $2002-07$ & Boreal & $1109,1413,1437,1565$ \\
\hline 3. N-Scandes/Latnjajaure (Sweden) & SE-LAT & 2001 & $2002-07$ & Boreal & $492,1000,1300,1560$ \\
\hline 4. S-Scandes/Dovrefjell (Norway) & NO-DOV & 2008 & $2002-07$ & Boreal & $1161,1418,1651,1845$ \\
\hline 5. Cairngorms (Scotland, United Kingdom) & UK-CAI & 2008 & $2002-07$ & Boreal & $742,904,978,1111$ \\
\hline 6. Central Caucasus/Kazbegi (Georgia) & GE-CAK & 2008 & $2003-07$ & Temperate & $2240,2477,2815,3024$ \\
\hline 7. E-Carpathians/Rodnei Mts (Romania) & RO-CRO & 2008 & $2002-07$ & Temperate & $2116,2063,2221,2268$ \\
\hline 8. W-Carpathians/High Tatras (Slovakia) & SK-CTA & 2008 & $2002-07$ & Temperate & $1919,2052,2061,2335$ \\
\hline 9. NE-Alps/Hochschwab (Austria) & AT-HSW & 2008 & $2002-07$ & Temperate & $1910,2065,2214,2255$ \\
\hline 10. S-Alps/Dolomites (Italy) & IT-ADO & 2008 & $2002-07$ & Temperate & $2199,2463,2757,2893$ \\
\hline 11. Central Alps/Texelgruppe (Italy) & IT-TEX & 2017 & $2014-16$ & Temperate & $2108,2619,3074,3287$ \\
\hline 12. Central Alps/SNP—carbonatic (Switzerland) & $\mathrm{CH}-\mathrm{SN} 1$ & 2015 & $2016-17$ & Temperate & $2438,2542,2836,3092$ \\
\hline 13. Central Alps/SNP—siliceous (Switzerland) & $\mathrm{CH}-\mathrm{SN} 2$ & 2015 & $2016-17$ & Temperate & $2424,2519,2797,3104$ \\
\hline 14. W-Alps/Valais (Switzerland) & CH-VAL & 2008 & $2002-07$ & Temperate & $2360,2550,2989,3212$ \\
\hline 15. W-Alps/Mont Avic (Italy) & IT-MAV & 2012 & $2013-17$ & Temperate & $2340,2584,2790,3014$ \\
\hline 16. Northern Apennines (Italy) & IT-NAP & 2008 & $2002-07$ & Temperate & $1722,1815,1855,1978$ \\
\hline 17. Central Pyrenees/Ordesa (Spain) & ES-CPY & 2008 & $2002-07$ & Temperate & $2242,2519,2779,3022$ \\
\hline 18. Corsica/Monte Cinto (France) & FR-CRI & 2001 & $2002-07$ & Mediter & $2144,2305,2607$ \\
\hline 19. Central Apennines/Majella (Italy) & IT-CAM & 2001 & $2002-05$ & Mediter & $2405,2511,2635,2737$ \\
\hline 20. Sierra Nevada-West (Spain) & ES-SNE & 2008 & $2002-07$ & Mediter & $2778,2968,3150,3327$ \\
\hline 21. Sierra Nevada—Northeast (Spain) & ES-SNN & 2011 & $2006-07$ & Mediter & $2668,2717,2800,3144$ \\
\hline 22. Crete/Lefka Ori (Greece) & GR-LEO & 2008 & 2002-07 & Mediter & $1664,1965,2160,2339$ \\
\hline
\end{tabular}

Columns are the GLORIA code, the year of the field survey used in analyses, the period with measurements of soil temperatures, the biome they belong to, and the elevation of the summits per region (Corsica counts only three summits)

Fig. 1 Distribution of the 22 GLORIA regions incorporated in the study. The inset enlarges the Alps and Northern Apennines. Corresponding region names and further information are given in Table 1

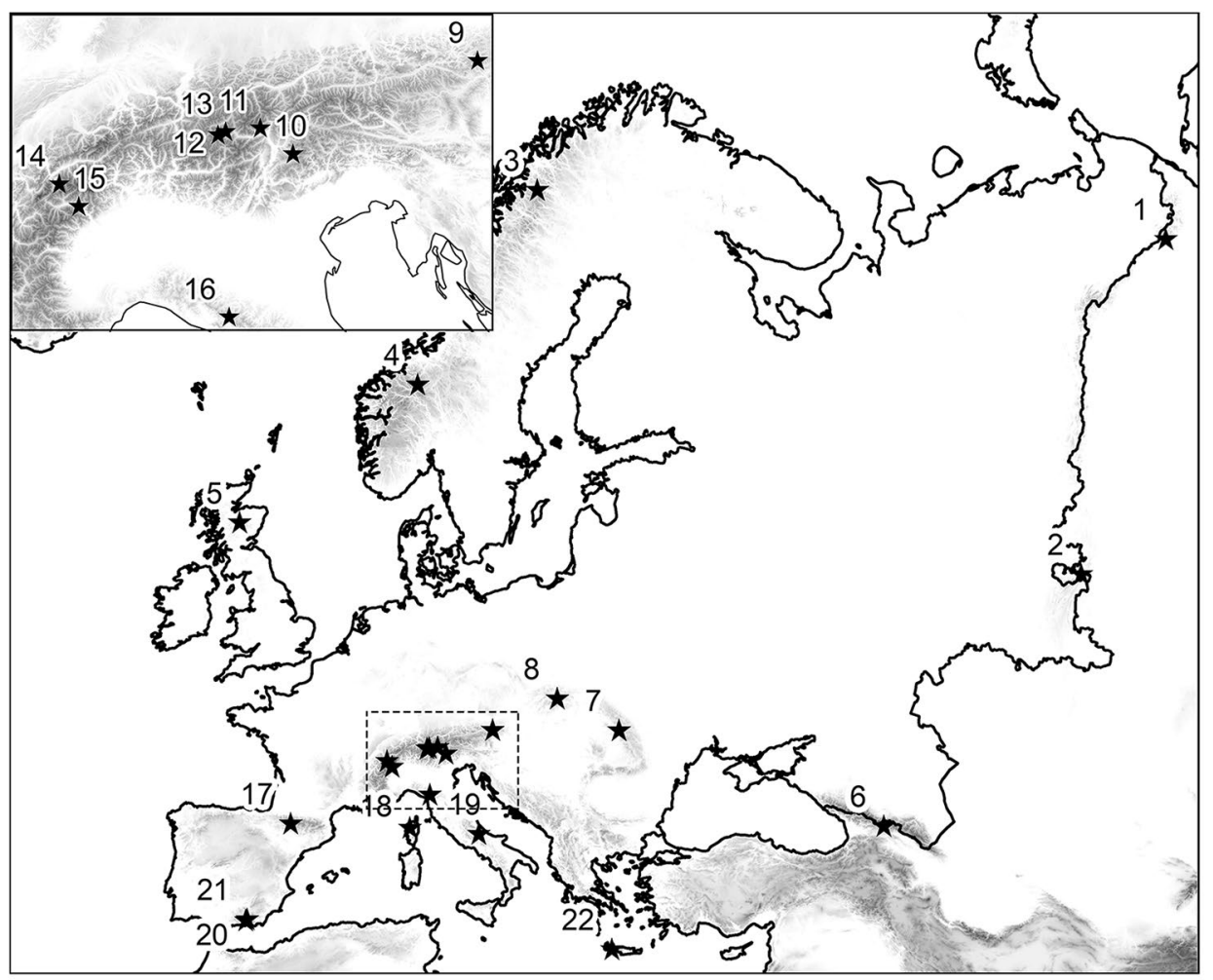


(distance from logger to the centre of each plot ca. $1.5 \mathrm{~m}$ ). Soil temperature was recorded in one-hour intervals. For most regions, the 2002-2007 measurement period was used for the analyses; in some regions, data were not available for the whole period (Table 1). Raw temperature time series were plotted and inspected visually for outliers, extreme values and sudden changes in amplitudes. Temperature records that fell outside the 0.05-99.95 percentile, often immediately before and after technical breaks (e.g., because of battery change), or subsequent readings exceeding a threshold of $4 \mathrm{~K}$ were excluded after comparison with simultaneous readings by neighbouring loggers.

\section{Data preparation}

Following Grabherr et al. (2003), the upper limit of the grassline was defined as the elevation where the total cover of vascular plants per plot fell below $40 \%$ (see Table S1 in Appendix 2 for alternative cover values). Since vascular plant growth may be co-determined locally by factors other than temperature at such high elevations (e.g. gravitational, periglacial and deflational processes, freeze-thaw cycles, water availability), only the $1 \mathrm{~m} \times 1 \mathrm{~m}$ plot with the highest vascular plant cover within each cluster was used in the analyses. We assumed that this plot offered the best conditions for plant growth on the local fine scale. In the other three pseudo-replicate plots per cluster, substrate-related factors, variation in disturbances or differences in slope or exposure are expected to have more strongly contributed to a lower plant cover. Consequently, selecting only the plot with the greatest plant cover of each cluster, up to the grassline, is the best way to limit the influence in the analyses of the other local factors that may limit vascular plant growth and to identify the upper limit of the fundamental niche of closed grasslands. Using the mean or the median of the four plots would have resulted in lower cover than the actual potential plant cover related to local microclimate (see Appendix 1 for results with the median). For the same reasons, five clusters located on slopes steeper than $45^{\circ}$ were discarded, since steepness favours unstable conditions and substrate solifluction, which are detrimental to plant cover.

Growing season length was calculated as the number of days in the year where the daily mean soil temperature at a depth of $10 \mathrm{~cm}$ was above a threshold level. Following previous studies (Theurillat et al. 1998; Körner et al. 2003; Körner 2011), three different temperature thresholds were utilised $\left(1{ }^{\circ} \mathrm{C}, 2^{\circ} \mathrm{C}\right.$ and $\left.5^{\circ} \mathrm{C}\right)$. Lower temperatures (e.g. $\left.0{ }^{\circ} \mathrm{C}\right)$ were not considered since days with snow cover would have been counted as belonging to the growing season. The threshold used by Körner and Paulsen (2004) in their global study of treelines $\left(3.2^{\circ} \mathrm{C}\right)$ was similarly rejected. This value has been specifically defined for root temperature at the treeline as corresponding approximately to a weekly mean canopy temperature of $0{ }^{\circ} \mathrm{C}$. It is therefore not directly applicable to grassland soils, which, in contrast to trees, are exposed to strong solar radiation. Because Mediterranean and oceanic regions can have rather long periods with warm conditions, the whole year was considered to potentially belong to the growing season, as long as the mean daily temperature was above the retained temperature threshold. The growing season can be interrupted by cold and/or snow cover events that are common under alpine conditions.

Seasonal mean soil temperature per logger was calculated from all days belonging to the growing seasons as defined above. Degree-days $\left({ }^{\circ} \mathrm{d}\right)$ per season were calculated by summing all daily temperatures above $1{ }^{\circ} \mathrm{C}$. For all clusters, the multi-year means of temperature, length of the growing seasons and degree-days were calculated by averaging all complete years available. Years with more than 20 missing days in temperature data were excluded, and sites having a temperature data series shorter than 2 years were excluded (13 clusters).

Out of the 87 summits with 344 clusters present in the original data set, 326 clusters were retained for analyses (five were discarded with a slope $\geq 45^{\circ}$ and 13 with insufficient logger data). The mean length of the temperature time series was $4.7 \pm 1.6$ years $(71 \%$ of clusters with time series of 4-7 years, and 29\% with 2-3 years; Table 1). For all regions, local atmospheric temperatures (ERA5; Copernicus Climate Change Service 2017; see Appendix 3 for details) during the periods of soil temperature measurements were found to be representative for the 1979-2019 period (within the $95 \%$ confidence interval; see Appendix 3).

\section{Statistical analyses}

The cover of vascular plants in the $1 \mathrm{~m} \times 1 \mathrm{~m}$ plots was plotted against their respective multi-year mean of growing season parameters (soil temperature, length and degreedays). We considered that plant cover, as a function of a given seasonal parameter, is constrained by two horizontal asymptotes: the lower one at $0 \%$ cover (absence of plants) in very cold conditions, and the upper one at or close to $100 \%$ cover in sufficiently warm conditions. Between these two extremes, we calculated the sigmoid following the highest observed cover for each value of seasonal parameter. In this way, the sigmoid can be assumed to follow the best potential conditions for vascular plant cover, limited by climatic conditions only. Plots situated under the sigmoid have a plant cover below the potential one due to other uncontrolled factors (e.g., unstable substrate, rock outcrop). To calculate the sigmoid, the $\mathrm{x}$-axis was divided into intervals of $0.5 \mathrm{~K}$ (for mean soil temperature), 10 days (for growing season length), or $100^{\circ} \mathrm{d}$ (for degree-days). For each interval, the 95 th percentile of all cover values which fell into the interval was 
calculated following the definition 7 of Hyndman and Fan (1996).

The sigmoid curve was fitted to the 95th percentiles of each interval using non-linear least squares (function $n l s$ in R; Bates and Watts 1988; Bates and Chambers 1992). The equation $y(x)=A+\frac{K-A}{1+e^{-B(x-M)}}$ was implemented for the sigmoid function, where $A$ is the value on the y-axis of the lower asymptote ( $0 \%$ as starting value), $K$ is the value on the $\mathrm{y}$-axis of the upper asymptote (also called carrying capacity, the maximum of all available points in the graph used as the starting value), $B$ is the slope of the curve between the two asymptotes, and $M$ the value on the x-axis of the sigmoid's mid-point. These four parameters were calculated by iteration convergence. The corresponding seasonal parameter value at a vascular plant cover of $40 \%$ was considered to represent the threshold for the grassline, that is, the upper limit of closed alpine vegetation. The potential differences between biomes (boreal, temperate and Mediterranean) and aspects were evaluated with the respective data subsets.

All data preparation and statistical analyses were done in R 3.5.1 (R Core Team 2018).

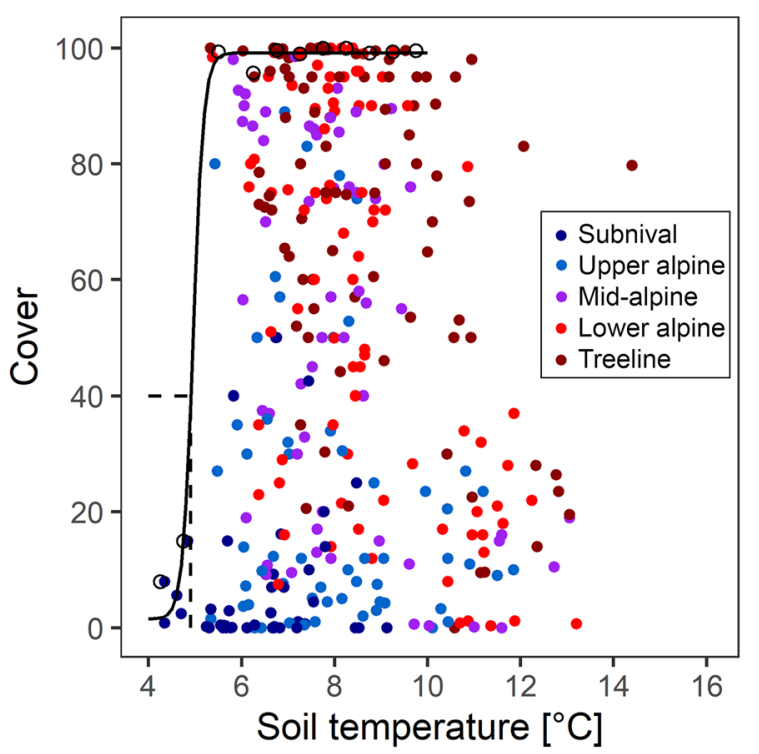

Fig. 2 Vascular plant cover in relation to mean soil temperature of the growing season $\left(4.9^{\circ} \mathrm{C}\right.$; left), and mean length of the growing season in days ( 85 days; right). Growing days were retained for mean daily soil temperatures $\geq 1{ }^{\circ} \mathrm{C}$ (see Fig. S3 in Electronic supplementary material for the other values). Filled circles correspond to individual $1 \mathrm{~m} \times 1 \mathrm{~m}$ plots (highest cover value in each $3 \mathrm{~m} \times 3 \mathrm{~m}$ cluster),

\section{Results}

Vascular plant cover decreased strongly below a mean soil temperature around $5-6{ }^{\circ} \mathrm{C}$ in the growing season. A vascular plant cover of $40 \%$ corresponded to a mean soil temperature of $4.9^{\circ} \mathrm{C}$ when the growing season was defined as encompassing days with a mean temperature $\geq 1{ }^{\circ} \mathrm{C}$ (Fig. 2). The temperature threshold climbed to $7.3{ }^{\circ} \mathrm{C}$ for a growing season calculated $\geq 5^{\circ} \mathrm{C}$ (Table 2; Fig. S3).

Similarly, plant cover decreased strongly below a growing season length of around 100 days (Fig. 2). The minimum growing season length allowing a vascular plant cover of $40 \%$ was calculated at 85 days for a growing season defined as days $\geq 1{ }^{\circ} \mathrm{C}$, and 40 days for days $\geq 5{ }^{\circ} \mathrm{C}$ (Table 2; Fig. S3). During the growing season, a minimum of 498 degreedays above $1{ }^{\circ} \mathrm{C}$ was necessary for the establishment of a plant cover of $40 \%$ (Table 2; Fig. S4).

When considering the three biomes separately (Fig. 3), boreal and temperate sites had similar thresholds for the mean soil temperature $\left(5.1^{\circ} \mathrm{C}\right.$ and $4.9^{\circ} \mathrm{C}$, respectively, for a growing season calculated $\geq 1{ }^{\circ} \mathrm{C}$ ). However, boreal summits were characterized by a shorter growing season length (83 days) than temperate summits (107 days; Table 2), with corresponding differences in the necessary degree-days (calculated above $1{ }^{\circ} \mathrm{C}$ ): $505^{\circ} \mathrm{d}$ on boreal summits and $683^{\circ} \mathrm{d}$ on temperate summits (Fig. S4). The available data for the

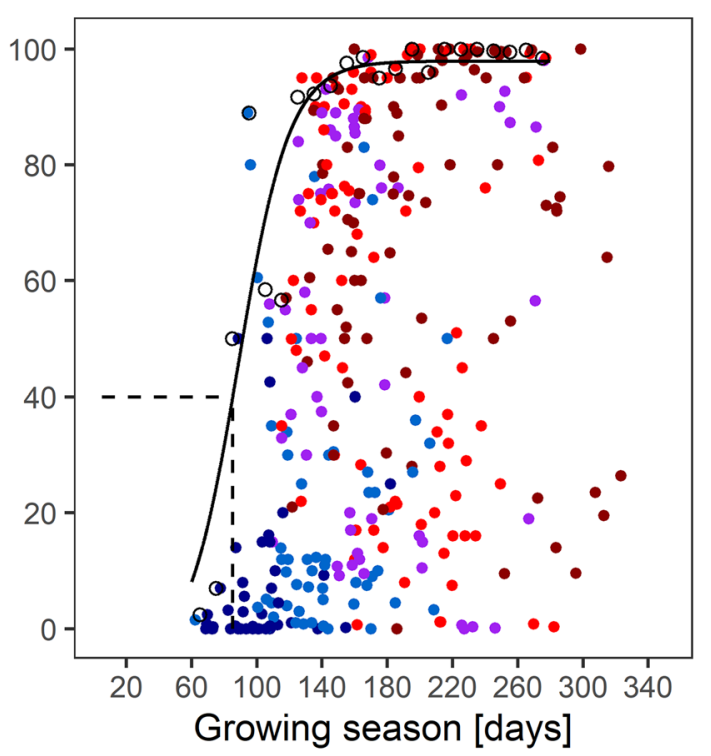

coloured according to the elevation belt of the summit. Open circles are the 95th percentile of each interval of soil temperatures or growing season values, respectively, used to calculate the sigmoid curve. Dashed lines refer to the $40 \%$ plant cover and the respective corresponding threshold values 
Table 2 Soil temperatures, length of the growing season and degree-days at the upper limit of the alpine grasslands

\begin{tabular}{lccccccc}
\hline & \multicolumn{2}{c}{ Temperature threshold $\left[{ }^{\circ} \mathrm{C}\right]$} & \multicolumn{2}{l}{$\begin{array}{l}\text { Threshold for the growing season } \\
\text { length [day }\end{array}$} & $\begin{array}{l}\text { Degree- } \\
\text { days } \\
{\left[{ }^{\circ} \mathrm{d}\right]}\end{array}$ \\
\hline $\begin{array}{l}\text { Temperature limit for a } \\
\text { growing day }\end{array}$ & $1{ }^{\circ} \mathrm{C}$ & $2{ }^{\circ} \mathrm{C}$ & $5{ }^{\circ} \mathrm{C}$ & $1{ }^{\circ} \mathrm{C}$ & $2{ }^{\circ} \mathrm{C}$ & $5{ }^{\circ} \mathrm{C}$ & $1{ }^{\circ} \mathrm{C}$ \\
$\begin{array}{l}\text { Complete data set } \\
\text { Biomes }\end{array}$ & 4.91 & 5.35 & 7.27 & 85.2 & 81.5 & 39.5 & 498 \\
$\begin{array}{l}\text { Boreal } \\
\text { Temperate }\end{array}$ & 5.10 & 5.65 & 7.36 & 83.4 & 81.9 & 41.8 & 505 \\
Mediterranean & 4.88 & 5.35 & 7.27 & 107.0 & 97.7 & 72.2 & 683 \\
\hline
\end{tabular}

Three levels of daily mean soil temperature were used for considering a day as a growing day. The data set was insufficient to calculate thresholds in the Mediterranean biome (see Fig. 3 and S3 for corresponding graphics)
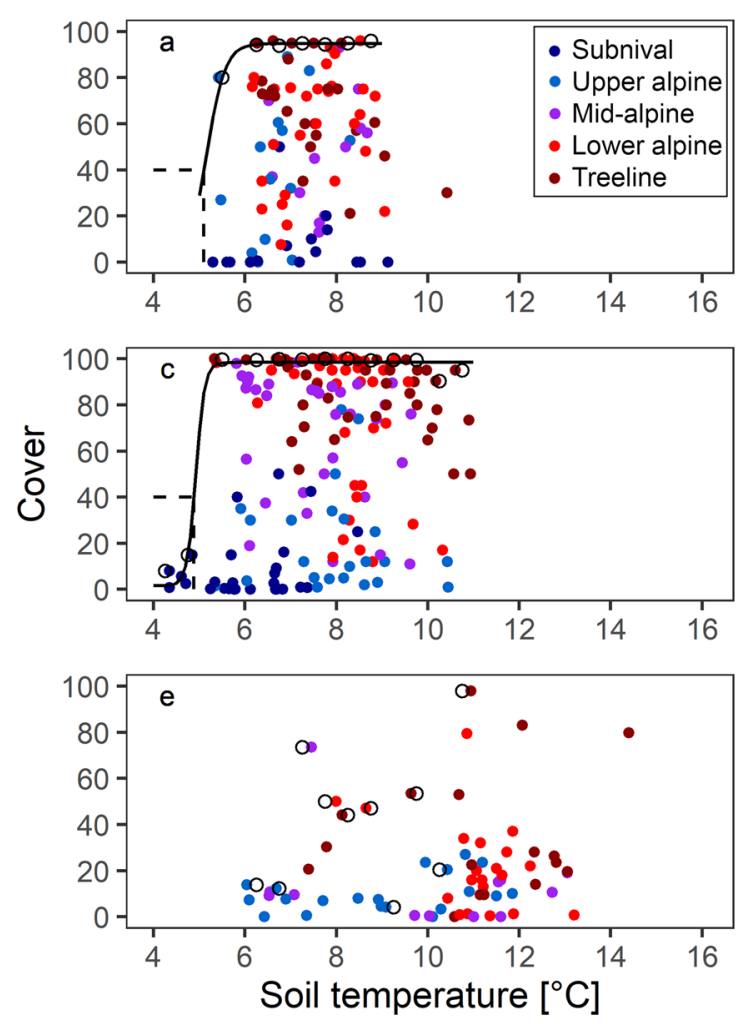

Fig. 3 Vascular plant cover on $\mathbf{a}, \mathbf{b}$ boreal, $\mathbf{c}, \mathbf{d}$ temperate, and $\mathbf{e}, \mathbf{f}$ Mediterranean summits in relation to mean soil temperature (left) and mean length of the growing season (right), when growing days are above a daily mean of $1{ }^{\circ} \mathrm{C}$. The sigmoids for the Mediterranean sum-

Mediterranean summits did not allow for the calculation of a sigmoid.

There were no obvious differences, neither for mean soil temperature nor for the growing season length, in relation to slope exposure (Fig. S5). However, the sigmoids could not be calculated for each exposure category separately due to an insufficient number of data points.
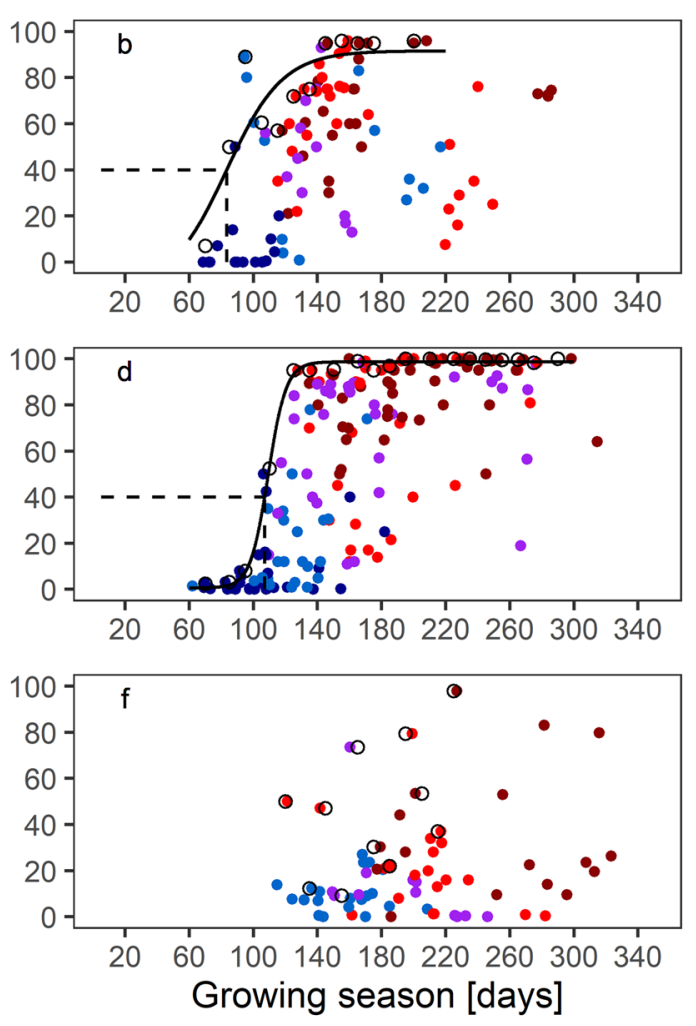

mits could not be calculated because of insufficient data and too variable plant covers in warm conditions. Filled, open circles and dashed lines as in Fig. 2. See Table 2 for corresponding threshold values

On the European scale, the mean length of the growing season was highly variable for a given mean soil temperature. For instance, the growing season length for a soil temperature around $6{ }^{\circ} \mathrm{C}$ ranged from 84 to 276 days (Fig. S6). Conversely, the soil temperatures for a growing season length around 110 days ranged from 4.9 to $9.0^{\circ} \mathrm{C}$, with growing degree-days between 523 and $974^{\circ} \mathrm{d}$, respectively. 


\section{Discussion}

The results, based on data of 87 summits distributed across Europe, suggest that alpine plant communities cannot exceed a vascular plant cover of $40 \%$ when the length of the growing season (days $\geq 1{ }^{\circ} \mathrm{C}$ ) is lower than 85 days, or when the mean soil temperature during the growing season is below $4.9^{\circ} \mathrm{C}$ (Fig. 2; Table 2).

\section{Temperature}

In this study, the threshold for seasonal mean temperature at $10 \mathrm{~cm}$ soil depth was around $5{ }^{\circ} \mathrm{C}$, which is similar to the thresholds for plant growth reported in previous studies; either as daily or seasonal mean values, or as lowest instantaneous temperature allowing plant growth. At the treeline, wood formation in conifers is strongly reduced when the daily mean air temperature is below $5.6-8.5^{\circ} \mathrm{C}$ (Rossi et al. 2007), and xylogenesis stops below $3-4{ }^{\circ} \mathrm{C}$ (Rossi et al. 2008). According to Körner and Paulsen (2004), the treeline corresponds to a mean soil temperature of $6.7 \pm 0.8{ }^{\circ} \mathrm{C}$ during the growing season (measured between 1996 and 2003). For low-stature arctic and alpine plant species, root growth is strongly reduced when soil temperatures drop below $5{ }^{\circ} \mathrm{C}$ (Nagelmüller et al. 2016), although some growth is still possible at $0-2{ }^{\circ} \mathrm{C}$ (e.g., Dupontia fisheri, Eriophorum angustifolium, Billings et al. 1977; Ranunculus glacialis, Poa alpina, Nagelmüller et al. 2017; Soldanella pusilla, Körner et al. 2019).

These observations point towards a physiological limit to growth for temperatures below ca. $5^{\circ} \mathrm{C}$. Carbon assimilation is an unlikely limiting factor, since the lower limit for net photosynthesis in alpine plants is close to the freezing tolerance of plant leaves $\left(-2\right.$ to $-6{ }^{\circ} \mathrm{C}$; Körner 2003). Rather, limitation of tissue formation (investment of the acquired carbon) has been suggested as a more likely mechanism (Hoch et al. 2002; Körner 2003; Hoch and Körner 2012). For instance, tree roots growing below $5{ }^{\circ} \mathrm{C}$ are less ramified, paler and more brittle than those growing at higher soil temperatures (Schenker et al. 2014). Cell elongation and xylem lignification are clearly inhibited around $1{ }^{\circ} \mathrm{C}$ in alpine plant species, with secondary roots being formed only rarely below $5{ }^{\circ} \mathrm{C}$ (Nagelmüller et al. 2017). Stalks of Soldanella pusilla can grow very slowly at $0{ }^{\circ} \mathrm{C}$ under the snow, with lignified xylem vessels. However, the sclerenchyma of the inner cortex only developed cell-wall lignification during warmer temperatures following snow melt (Körner et al. 2019).

Alpine plants are able to grow at higher elevations than trees because of their low stature. Indeed, in the European Alps, the alpine zone extends over $700 \mathrm{~m}$ in elevation above the treeline (Theurillat and Guisan 2001), corresponding to a mean air temperature ca. $4.2 \mathrm{~K}$ lower at the grassline than at the treeline, assuming an adiabatic lapse rate of $0.6{ }^{\circ} \mathrm{C} / 100 \mathrm{~m}$. Nevertheless, the difference between mean soil temperatures of the two ecotones in growing season was found to be much smaller: $4.9{ }^{\circ} \mathrm{C}$ at the grassline (growing season $\geq 1{ }^{\circ} \mathrm{C}$; Table 2) and $6.7 \pm 0.8^{\circ} \mathrm{C}$ at the treeline (start and end of the growing season $\geq 3.2{ }^{\circ} \mathrm{C}$; Körner and Paulsen 2004). This discrepancy between soil and air temperatures can be explained by contrasted effects of solar radiations on plants. At the treeline, tree canopy temperature is coupled to atmospheric temperature, with little heating effect through solar radiation. This was corroborated by model predictions of mean air temperature at treeline using WorldClim data (30 year means), which resulted in a very similar mean air temperature of $6.4{ }^{\circ} \mathrm{C}$ (Paulsen and Körner 2014) as the mean soil temperature of $6.7{ }^{\circ} \mathrm{C}$ during growing season (Körner and Paulsen 2004). Conversely, the short-growing alpine plants are exposed to strong soil heating by solar radiation (Wilson et al. 1987). For example, Scherrer and Körner (2010) found root temperatures under alpine grasslands to be $2-4 \mathrm{~K}$ warmer than air temperature in summer.

\section{Length of the growing season}

The length of the growing season can be a limiting factor for closed alpine vegetation in some habitats. The observed thresholds (40-85 days, for a growing season above $5{ }^{\circ} \mathrm{C}$ or $1{ }^{\circ} \mathrm{C}$, respectively) are in accordance with Theurillat et al. (1998), who set the upper limit of the closed alpine vegetation in the European Alps at 50 growing days with air temperature above $5{ }^{\circ} \mathrm{C}$. This threshold for closed alpine vegetation is shorter than the mean treeline threshold of around 126 days, but close to the absolute minimum of 91 days (with a growing season $\geq 3.2^{\circ} \mathrm{C}$; Körner and Paulsen 2004).

According to Körner (2003), a leaf of Ranunculus glacialis at $2600 \mathrm{~m}$ a.s.l needs 37 days to amortize the carbon investment of leaf production, and 40-50 days is generally considered as the minimum for alpine vascular plant to survive in snowbeds. In a transplantation experiment in the Himalayas, Klimeš and Doležal (2010) observed that the highest surviving plants, at $6030 \mathrm{~m}$ a.s.l., had 47 days above $0{ }^{\circ} \mathrm{C}$, but none of the species survived at $6160 \mathrm{~m}$ a.s.l with only 19 days above $0{ }^{\circ} \mathrm{C}$. Wagner et al. (2012) noted that 40-44 days was the strict minimum after snowmelt to achieve seed maturity, but most of the species needed 60-100 days to reproduce in the subnival belt.

These timespans apply to forbs particularly adapted to cold conditions. Some of them are able to reproduce clonally, but without being able to form extensive cover. However, one may hypothesize that longer and warmer growing seasons are necessary for species with an efficient enough 
clonal reproduction (e.g., Poaceae and Cyperaceae) for forming closed grasslands. Another important biological trait to build alpine grasslands is longevity insuring the continuity of the plant cover. However, long longevity could be particularly limited by low mean temperatures, as these are associated to a higher frequency of extremely adverse conditions, liable to damage or kill plants. Once graminoids, or other clonal species, have colonized a surface, one can assume that they create a virtuous loop towards the development of dense grasslands: graminoids are particularly effective in capturing aeolian sediments (Küfmann 2003), and their dense roots strongly contribute to accumulation of below-ground organic material and to stabilisation of fine soil material (Schröter 1926; Jenny-Lips 1948). This initial soil improves water and nutrient availability and the retention of heat from solar radiation. These are important factors that favour colonisation of additional species, which in turn contribute to the stability of the whole system.

With a reduced growing season length with elevation, periglacial, gravitational and deflation processes take more and more importance, preventing non-pioneer plants from establishing, developing and persisting (Klimeš 2003). However, the most important clonal graminoids in alpine vegetation are not pioneer species and need some stability to develop closed grasslands (Schröter 1926). Therefore, the thresholds of $4.9^{\circ} \mathrm{C}$ and 85 days for the growing season corresponds to a tipping point regarding the minimum necessary warmth for efficient clonal plants, mostly graminoids in the northern hemisphere, to develop closed grasslands. In colder conditions, plant life is still possible, but as more or less isolated individuals. For example, Dvorský et al. (2015) observed five plant species in Ladakh at 6150 m.a.s.l, with a mean soil temperature of $2.9^{\circ} \mathrm{C}$, whilst Körner (2011) described the life conditions of a Saxifraga oppositifolia cushion at $4507 \mathrm{~m}$.a.s.1 in the Alps, with a mean temperature of $2.6^{\circ} \mathrm{C}$ for 66 days with a mean rooting temperature $>0{ }^{\circ} \mathrm{C}$.

\section{Latitude and slope orientation}

The minimum soil temperatures for closed vegetation are quite similar in the boreal and temperate sites, suggesting that a universal threshold exists. However, the length of the growing season is longer in the temperate than in the boreal sites, hence corresponding to a much higher sum of degree-days on temperate summits. A similar difference was observed for the treeline, with $104 \pm 2$ growing days in three Eurasian subarctic and boreal sites, against $135 \pm 10$ days for 12 temperate sites in the Alps (Körner and Paulsen 2004). With a worldwide scope, these authors concluded that the growing season length alone has no explanatory power for the treeline, since it can be up to 365 days at the equator. We can realistically hypothesize the same latitudinal pattern for the grassline. Unfortunately, we could not test this with the Mediterranean biome, as very high summits with cold enough conditions to exclude grassland development were not available in our dataset (Fig. 3 and S6).

As expected, the thresholds for mean growing season temperature and season length for closed alpine vegetation appear similar for all aspects (Fig. S5). However, the elevation of the grassline differs among aspects and along the latitudinal gradient. The thermal grassline limit is not reached in Sierra Nevada (Spain, $37.1^{\circ} \mathrm{N}$ ) at $3327 \mathrm{~m}$ a.s.l. (the elevation of its highest study summit), but it lies at around $2990 \mathrm{~m}$ a.s.l. in the Swiss Alps $\left(46.0^{\circ} \mathrm{N}\right)$ and around $1560 \mathrm{~m}$ a.s.l. in the Northern Scandes (Sweden, $68.3^{\circ} \mathrm{N}$ ), in both cases on the north-facing aspect. Similarly, the grassline is located higher on the south- or east-facing slopes than on west- and north-facing ones, as south and east are warmer than north and west slopes (Winkler et al. 2016). According to our data set, with south-facing slopes ca. $0.62 \mathrm{~K}$ warmer than north-facing slopes on the upper alpine and subnival summits (analysis not shown, data available as supplementary material), one can expect a grassline situated approximately $100 \mathrm{~m}$ higher on south-facing than on north-facing slopes (temperature lapse rate of $0.6{ }^{\circ} \mathrm{C} / 100 \mathrm{~m}$ ). This difference contrasts with the situation at the treeline. At the grassline, the root temperature of the low-stature plants depends on the solar radiation reaching the soil surface, whereas at the treeline, exposure effects are buffered by tree canopies (Paulsen and Körner 2001; Körner and Paulsen 2004).

\section{Supplementary factors affecting thresholds}

The low number of plots with a plant cover close to $0 \%$ due to cold conditions or short-growing season limits the precision of the calculated thresholds. Such data are absent because most of the GLORIA target regions have no subnival or nival summits or because only summits with plants were selected. In addition, in the absence of plants, soil is generally missing and measuring soil temperature is not possible. Conversely, although the $1 \mathrm{~m} \times 1 \mathrm{~m}$ plot with the highest vascular plant cover per quadrat cluster was selected for analyses, many sites have plots with $0 \%$ cover in warmer conditions than the calculated thresholds. According to the GLORIA field manual, the clusters are always set $5 \mathrm{~m}$ below the summit (Pauli et al. 2015). Thus, plot positions may not represent the best local conditions for plant growth. Indeed, plots may be situated on limestone pavements, scree or steep slope; all situations where plant colonisation is strongly inhibited by the absence of fine substrate or its instability. In the Mediterranean sites, summer drought adds an important stress which probably explains the very low plant cover recorded in many plots, despite growing seasons exceeding $11^{\circ} \mathrm{C}$ and 200 days (Pescador et al. 2016; Fig. 3e, f). Lamprecht et al. (2021) showed that on Sierra Nevada summits 
(Spain), changes in vegetation cover are independent of temperature variations but are related to rainfall variations.

A further reason of deviation may arise from the potential mismatch between (1) the present distribution of the limit to closed alpine vegetation, which is mostly a legacy of the prevailing climate before the 1980s, and (2) the recorded soil temperatures in the 2000 s that were already influenced by ongoing climatic warming (Qian et al. 2011; Fig. S2). For example, in the Swiss Alps, air temperature increased by $0.57{ }^{\circ} \mathrm{C}$ per decade at the end of the twentieth century (Rebetez and Reinhard 2008) and snow cover duration decreased by 8.9 days per decade (Klein et al. 2016). In the Southern Scandes (Norway), air temperature increased by $0.34{ }^{\circ} \mathrm{C}$ and the growing season by 6.2 days per decade since the 1960s (Michelsen et al. 2011). In the Central Apennines, air temperature increased by $0.26{ }^{\circ} \mathrm{C}$ per decade during the last half of the twentieth century (Evangelista et al. 2016). However, this large-scale trend has some exceptions, such as in the Cairngorms (Scotland), where snow cover duration increased locally between 2002 and 2015 by around $81 \pm 21$ days (Andrews et al. 2016). Although the process of species colonization is rapid on European alpine summits (e.g., Pauli et al. 2012; Matteodo et al. 2013; Steinbauer et al. 2018), one can reasonably expect that the development of closed vegetation is much slower in the subnival belt (Kulonen et al. 2018; Lamprecht et al. 2018). Therefore, actual threshold values for the European grassline at $10 \mathrm{~cm}$ soil depth are probably slightly lower than the calculated $4.9{ }^{\circ} \mathrm{C}$ and 85 days for mean soil temperature and growing season length. Conversely, root meristems of alpine plants are often situated only $1-3 \mathrm{~cm}$ below soil surface (Körner 2003). Therefore, the actual mean temperature for growth at the grassline is expected to be warmer than the calculated values.

\section{Conclusion}

The alpine-nival ecocline is defined as the transition between the closed alpine grasslands and the mostly unvegetated nival zone (Reisigl and Pitschmann 1958; Leuschner and Ellenberg 2017). On the basis of the species composition and snow cover, Gottfried et al. (2011) calculated an elevation around 2900-2970 $\mathrm{m}$ for the alpine-nival ecocline in the European Alps, corresponding approximately to the summer snow line (Hantel et al. 2012). According to our analyses, a mean soil temperature above $4.9^{\circ} \mathrm{C}$ during the growing season, defined as encompassing days with daily mean temperatures $\geq 1{ }^{\circ} \mathrm{C}$, is necessary for the presence of closed alpine swards, a value close to that observed in soils of treeline habitats (Körner and Paulsen 2004). This temperature threshold is in accordance with several studies on vascular plant growth under cold conditions dealing with plant physiology or alpine ecology (e.g., Billings et al. 1977; Nagelmüller et al. 2016). As expected, with a minimum of 85 days $\geq 1{ }^{\circ} \mathrm{C}$, the length of the growing season is an intermediate value between the shortest possible time for the growth of vascular plants (40-50 days) and the shortest growing season length observed at the treeline (91 days between the first and last days $\geq 3.2{ }^{\circ} \mathrm{C}$; Körner and Paulsen 2004).

Based on a large data set, our study confirmed previous values hypothesized for the climatic conditions determining the grassline at the alpine-nival ecocline (e.g., Theurillat et al. 1998; Körner 2003) and improved our understanding of the upper limit of closed alpine swards in high mountains. Complementary studies in mountain ranges of other continents, especially in tropical, subtropical and arid-temperate regions, would be required for a global assessment. As with the treeline, the minimum mean soil temperature value for the presence of a closed alpine vegetation is expected to be approximately the same everywhere, whilst the growing season length increases towards the equator. Studies focusing on soil formation and biotic processes at the grassline and on the cold-adaptations of different growth forms would be important for a better understanding of the grassline and its potential to move upwards under climate change.

Supplementary Information The online version contains supplementary material available at https://doi.org/10.1007/s00035-021-00250-1.

Acknowledgements We thank the numerous collaborators in each region who participated in field inventories, S. Jordan for his preliminary analyses, and A.-L. Aeby and F. Schütz for their assistance on statistical analyses. We are particularly grateful to C. Körner and two anonymous reviewers for their helpful comments on earlier versions of the manuscript.

Author contributions SB and PV conducted data analyses and wrote the first draft of the manuscript, HP is cofounder of the GLORIA programme, HP, AL, KS and MW are coordinating the GLORIA network and manage the database, all authors provided vegetation and temperature data from their region and contributed to the manuscript.

Funding Open Access funding provided by Université de Lausanne. Field inventories and temperature loggers were financially supported by 5th RTD Framework Programme of the European Union, UK Centre for Ecology and Hydrology, Département de la culture et des sports du Valais, Departamento de Medio Ambiente del Gobierno de Aragón, Foundation Dr. Joachim de Giacomi, Fondation Mariétan, Italian project of strategic interest NextData, MAVA Foundation, Frignano Regional Park (Modena), Norwegian Environment Agency, Ordesa \& Monte Perdido National Park, Research Commission of the Swiss National Park, Scientific Grant Agency VEGA (project Nr. 2/0132/18), Scottish Natural Heritage, Sierra Nevada National Park, Société académique de Genève, Swiss Federal Office of Education and Science, Swiss Federal Office for the Environment, Tiroler Wissenschaftsfonds, 
Tuscan-Emilian Apennines National Park, and Wissenschaftsförderung der Südtiroler Landesregierung.

Data availability All summit data, top cover of vascular plants, multiannual mean temperatures in growing season, and the length of the growing season are available as downloadable files in the supporting information. The precise location and name of the GLORIA summits are protected to avoid potential deterioration of the long-term monitoring sites.

\section{Compliance with ethical standards}

Conflict of interest The authors declare no conflict of interest.

Open Access This article is licensed under a Creative Commons Attribution 4.0 International License, which permits use, sharing, adaptation, distribution and reproduction in any medium or format, as long as you give appropriate credit to the original author(s) and the source, provide a link to the Creative Commons licence, and indicate if changes were made. The images or other third party material in this article are included in the article's Creative Commons licence, unless indicated otherwise in a credit line to the material. If material is not included in the article's Creative Commons licence and your intended use is not permitted by statutory regulation or exceeds the permitted use, you will need to obtain permission directly from the copyright holder. To view a copy of this licence, visit http://creativecommons.org/licenses/by/4.0/.

\section{References}

Andrews C, Ives S, Dick J (2016) Long-term observations of increasing snow cover in the western Cairngorms. Weather 71:178-181

Bates DM, Chambers JM (1992) Nonlinear models. In: Chambers JM, Hastie TJ (eds) Statistical Models in S. Wadsworth \& Brooks/Cole, Pacific Grove, pp 421-445

Bates DM, Watts DG (1988) Nonlinear regression analysis and its applications. John Wiley \& Sons, Chichester

Billings WD, Peterson KM, Shaver GR, Trent AW (1977) Rootgrowth, respiration, and carbon-dioxide evolution in an Arctic tundra soil. Arct Alp Res 9:129-137

Brockmann-Jerosch H (1919) Baumgrenze und Klimatcharakter. Beitr Geobot Landesaufn Schweiz 6:1-255

Copernicus Climate Change Service (C3S) (2017) ERA5: Fifth generation of ECMWF atmospheric reanalyses of the global climate. Copernicus Climate Change Service Climate Data Store (CDS). https://cds.climate.copernicus.eu/cdsapp

Crawford RMM (2008) Plants at the margin: ecological limits and climate change. Cambridge University Press, Cambridge

Dvorský M, Altman J, Kopecký M, Chlumská Z, Řeháková K, Janatková K, Doležal J (2015) Vascular plants at extreme elevations in eastern Ladakh, northwest Himalayas. Plant Ecol Divers 8:571-584

Dvorský M, Macek M, Kopecký M, Wild J, Doležal J (2017) Niche asymmetry of vascular plants increases with elevation. J Biogeogr 44:1418-1425

Evangelista A, Frate L, Carranza ML, Attorre F, Pelino G, Stanisci A (2016) Changes in composition, ecology and structure of highmountain vegetation: a re-visitation study over 42 years. AoB PLANTS 8:1-11

Gottfried M, Hantel M, Maurer C, Töchterle R, Pauli H, Grabbherr G (2011) Coincidence of the alpine-nival ecotone with the summer snowline. Environ Res Lett 6:014013
Gottfried M, Pauli H, Futschik A, Akhalkatsi M, Barančok P et al (2012) Continent-wide response of mountain vegetation to climate change. Nat Clim Chang 2:111-115

Gottfried M, Pauli H, Reiter K, Grabherr G (2002) Potential effects of climate change on alpine and nival plants in the Alps. In: Körner C, Spehn EM (eds) Mountain biodiversity - a global assessment. Parthenon Publishing, London, pp 213-223

Grabherr G, Nagy L, Thompson DBA (2003) Overview: an outline of Europe's alpine areas. In: Nagy L, Grabherr G, Körner C, Thompson DBA (eds) Alpine Biodiversity in Europe. Springer, Berlin, pp 3-12

Hantel M, Maurer C, Mayer D (2012) The snowline climate of the Alps 1961-2010. Theor App Clim 110:517-537

Hoch G, Körner C (2012) Global patterns of mobile carbon stores in trees at the high-elevation tree line. Glob Ecol Biogeogr 21:861-871

Hoch G, Popp M, Körner C (2002) Altitudinal increase of mobile carbon pools in Pinus cembra suggests sink limitation of growth at the Swiss treeline. Oikos 98:361-374

Hyndman RJ, Fan YN (1996) Sample quantiles in statistical packages. Am Stat 50:361-365

Häsler R, Streule A, Turner H (1999) Shoot and root growth of young Larix decidua in contrasting microenvironments near the alpine treeline. Phyton 39:42-52

Jenny-Lips H (1948) Vegetation der Schweizer Alpen. Büchergilde Gutenberg, Zürich

Klein G, Vitasse Y, Rixen C, Marty C, Rebetez M (2016) Shorter snow cover duration since 1970 in the Swiss Alps due to earlier snowmelt more than to later snow onset. Clim Chang 139:637-649

Klimeš L (2003) Life-forms and clonality of vascular plants along an altitudinal gradient in E Ladakh (NW Himalayas). Bas Appl Ecol 4:317-328

Klimeš L, Doležal J (2010) An experimental assessment of the upper elevational limit of flowering plants in the western Himalayas. Ecography 33:590-596

Kulonen A, Imboden RA, Rixen C, Maier SB, Wipf S (2018) Enough space in a warmer world? Microhabitat diversity and small-scale distribution of alpine plants on mountain summits. Divers Distrib 24:252-261

Körner C (2003) Alpine plant life, 2nd edn. Springer, Berlin

Körner C (2011) Coldest places on earth with angiosperm plant life. Alpine Bot 121:11-22

Körner C (2012) Alpine treelines: functional ecology of the global high elevation tree limits. Springer, Heidelberg

Körner C, Paulsen J (2004) A world-wide study of high altitude treeline temperatures. J Biogeogr 31:713-732

Körner C, Paulsen J, Pelaez-Riedl S (2003) A bioclimatic characterisation of Europe's alpine areas. In: Nagy L, Grabherr G, Körner C, Thompson DBA (eds) Alpine Biodiversity in Europe. Springer, Berlin, pp 13-28

Körner C, Riedl S, Keplinger T, Richter A, Wiesenbauer J, Schweingruber $\mathrm{F}$, Hiltbrunner $\mathrm{E}(2019)$ Life at $0^{\circ} \mathrm{C}$ : the biology of the alpine snowbed plant Soldanella pusilla. Alpine Bot 129:63-80

Küfmann C (2003) Soil types and eolian dust in high-mountainous karst of the Northern Calcareous Alps (Zugspitzplatt, Wetterstein Mountains, Germany). CATENA 53:211-227

Lamprecht A, Semenchuk PR, Steinbauer K, Winkler M, Pauli H (2018) Climate change leads to accelerated transformation of high-elevation vegetation in the central Alps. New Phytol 220:447-459

Lamprecht A, Pauli H, Fernández Calzado MR, Lorite J, Molero Mesa J, Steinbauer K, Winkler M (2021) Changes in plant diversity in a water-limited and isolated high-mountain range (Sierra Nevada, Spain). Alpine Bot. https://doi.org/10.1007/s00035-021-00246-x 
Leuschner C, Ellenberg H (2017) Vegetation ecology of Central Europe. 2. Ecology of Central European non-forest vegetation: coastal to alpine, natural to man-made habitats. Springer, Cham

Lortie CJ, Brooker RW, Choler P, Kikvidze Z, Michalet R, Pugnaire FI, Callaway RM (2004) Rethinking plant community theory. Oikos 107:433-438

Matteodo M, Wipf S, Stöckli V, Rixen C, Vittoz P (2013) Elevation gradient of successful plant traits for colonizing alpine summits under climate change. Environ Res Lett 8:024043

Michelsen O, Syverhuset AO, Pedersen B, Holten JI (2011) The impact of climate change on recent vegetation changes on Dovrefjell, Norway. Diversity 3:91-111

Nagelmüller S, Hiltbrunner E, Körner C (2016) Critically low soil temperatures for root growth and root morphology in three alpine plant species. Alpine Bot 126:11-21

Nagelmüller S, Hiltbrunner E, Körner C (2017) Low temperature limits for root growth in alpine species are set by cell differentiation. AoB PLANTS 9:plx054

Pauli H, Gottfried M, Dullinger S, Abdaladze O, Akhalkatsi M et al (2012) Recent plant diversity changes on Europe's mountain summits. Science 336:353-355

Pauli H, Gottfried M, Grabherr G (1999) Vascular plant distribution patterns at the low-temperature limits of plant life - the alpinenival ecotone of Mount Schrankogel (Tyrol, Austria). Phytocoenologia 29:297-325

Pauli H, Gottfried M, Lamprecht A, Niessner S, Rumpf S et al (2015) The GLORIA field manual - standard Multi-Summit approach, supplementary methods and extra approaches. GLORIACoordination Austrian Academy of Sciences \& University of Natural Resources and Life Sciences, Vienna

Paulsen J, Körner C (2001) GIS-analysis of treeline elevation in the Swiss Alps suggests no exposure effect. J Veg Sci 12:817-824

Paulsen J, Körner C (2014) A climate-based model to predict potential treeline position around the globe. Alpine Bot 124:1-12

Pescador DS, Sierra-Almeida Á, Torres PJ, Escudero A (2016) Summer freezing resistance: a critical filter for plant community assemblies in Mediterranean high mountains. Front Plant Sci 7:194

Qian B, Gregorich EG, Gameda S, Hopkins DW, Wang XL (2011) Observed soil temperature trends associated with climate change in Canada. J Geophys Res-Atmos 116:D02106

R Core Team (2018) R: A language and environment for statistical computing. R Foundation for Statistical Computing, Vienna. URL https://www.R-project.org/

Rebetez M, Reinhard M (2008) Monthly air temperature trends in Switzerland 1901-2000 and 1975-2004. Theor App Clim 91:27-34

Reisigl H, Pitschmann H (1958) Obere Grenzen von Flora und Vegetation in der Nivalstufe der Zentralen Ötztaler Alpen Tirol. Vegetatio 8:93-129

Rogora M, Frate L, Carranza ML, Freppaz M, Stanisci A et al (2018) Assessment of climate change effects on mountain ecosystems through a cross-site analysis in the Alps and Apennines. Sci Total Environ 624:1429-1442
Rossi S, Deslauriers A, Anfodillo T, Carraro V (2007) Evidence of threshold temperatures for xylogenesis in conifers at high altitudes. Oecologia 152:1-12

Rossi S, Deslauriers A, Gricar J, Seo JW, Rathgeber CBK, Anfodillo T, Morin H, Levanic T, Oven P, Jalkanen R (2008) Critical temperatures for xylogenesis in conifers of cold climates. Global Ecol Biogeogr 17:696-707

Schenker G, Lenz A, Körner C, Hoch G (2014) Physiological minimum temperatures for root growth in seven common European broadleaved tree species. Tree Physiol 34:302-313

Scherrer D, Körner C (2010) Infra-red thermometry of alpine landscapes challenges climatic warming projections. Global Change Biol 16:2602-2613

Schröter C (1926) Das Pflanzenleben der Alpen, 2nd edn. Raustein, Zürich

Steinbauer MJ, Grytnes JA, Jurasinski G, Kulonen A, Pauli H et al (2018) Accelerated increase in plant species richness on mountain summits is linked to warming. Nature 556:231-234

Theurillat JP, Felber F, Geissler P, Gobat JM, Fierz M et al (1998) Sensitivity of plant and ecosystems of Alps to climate change. In: Cebon P, Dahinden U, Davies H, Imboden D, Jaeger C (eds) A view from the Alps: regional perspectives on climate change. MIT Press, London, pp 225-308

Theurillat JP, Guisan A (2001) Potential impact of climate change on vegetation in the European Alps: a review. Climatic Change 50:77-109

Wagner J, Ladinig U, Steinacher G, Larl I (2012) From the flower bud to the mature seed: timing and dynamics of flower and seed development in high-mountain plants. In: Lütz C (ed) Plants in alpine regions: cell physiology of adaption and survival strategies. Springer, Wien, pp 135-152

Walter H, Breckle SW (1985) Ecological systems of the geobiosphere. 1. Ecological principles in global perspective. Springer, Heidelberg

Walther GR, Gritti ES, Berger S, Hickler T, Tang ZY, Sykes MT (2007) Palms tracking climate change. Global Ecol Biogeogr 16:801-809

Wilson C, Grace J, Allen S, Slack F (1987) Temperature and stature: a study of temperatures in montane vegetation. Funct Ecol $1: 504-413$

Winkler M, Illmer P, Querner P, Fischer BM, Hofmann K, Lamprecht A, Praeg N, Schied J, Steinbauer K, Pauli H (2018) Side by side? Vascular plant, invertebrate, and microorganism distribution patterns along an alpine to nival elevation gradient. Arct Antarct Alp Res 50:e1475951

Winkler M, Lamprecht A, Steinbauer K, Hülber K, Theurillat JP et al (2016) The rich sides of mountain summits: a pan-European view on aspect preferences of alpine plants. J Biogeogr 43:2261-2273

Publisher's Note Springer Nature remains neutral with regard to jurisdictional claims in published maps and institutional affiliations.

\section{Authors and Affiliations}

Sarah Bürli ${ }^{1,2}(\mathbb{D}) \cdot$ Jean-Paul Theurillat ${ }^{3,4}\left(\mathbb{C}^{\circ} \cdot\right.$ Manuela Winkler $^{5,6}(\mathbb{C}) \cdot$ Andrea Lamprecht $^{5,6}$ (1) Harald Pauli ${ }^{5,6}$ (D)

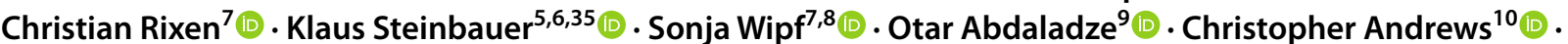

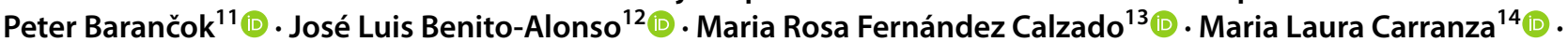
Jan Dick ${ }^{10}$ - Brigitta Erschbamer ${ }^{15}$ (D) Dany Ghosn ${ }^{16}$ (อ) Khatuna Gigauri $^{17}\left(\mathbb{D}^{1} \cdot\right.$ George Kazakis $^{16} \cdot$ Martin Mallaun $^{18}$. Ottar Michelsen ${ }^{19}$ (1) Dmitry Moiseev ${ }^{20}$. Pavel Moiseev ${ }^{20}$. Ulf Molau $^{21}$. Joaquín Molero Mesa ${ }^{13}$ (1) Umberto Morra di Cella ${ }^{22}$ (i) - Imran Nadeem ${ }^{23}$ (i) - Laszlo Nagy ${ }^{24}$ - Lena Nicklas ${ }^{15}$ (i) $\cdot$ Andrej Palaj ${ }^{11}$ (i) .

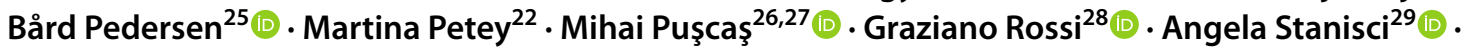




\section{Marcello Tomaselli ${ }^{30}$ (D) $\cdot$ Peter Unterluggauer ${ }^{31} \cdot$ Tudor-Mihai Ursu $^{32}$ (D) Luis Villar ${ }^{33} \cdot$ Pascal Vittoz $^{34}$ (D)}

1 Department of Ecology and Evolution, Faculty of Biology and Medicine, University of Lausanne, 1015 Lausanne, Switzerland

2 Botanical Garden of the University of Bern, Altenbergrain 21, 3013 Bern, Switzerland

3 Fondation J.-M. Aubert, 1938 Champex-Lac, Switzerland

4 Department of Botany and Plant Biology, University of Geneva, Case postale 71, 1292 Chambésy, Switzerland

5 GLORIA Coordination, Institute for Interdisciplinary Mountain Research, Austrian Academy of Sciences (ÖAW-IGF), Silbergasse 30/3, 1190 Vienna, Austria

6 GLORIA Coordination, Department of Integrative Biology and Biodiversity Research, University of Natural Resources and Life Sciences, Vienna (BOKU-DIB), Silbergasse 30/3, 1190 Vienna, Austria

7 WSL Institute for Snow and Avalanche Research SLF, Flüelastr. 11, 7260 Davos, Switzerland

8 Swiss National Park, Runatsch 124, Chastè Planta-Wildenberg, 7530 Zernez, Switzerland

9 Institute of Ecology, Ilia State University, Cholokashvili Ave, 3/5, 0162 Tbilisi, Georgia

10 UK Centre for Ecology and Hydrology, Bush Estate, Penicuik EH26 0QB, UK

11 Institute of Landscape Ecology, Slovak Academy of Sciences, Štefánikova 3, 81499 Bratislava, Slovak Republic

12 Jolube Botanical Consultant, 22700 Jaca, Huesca, Spain

13 Department of Botany, University of Granada, 18071 Granada, Spain

14 EnvixLab, Department of Bioscience and Territory, University of Molise, Contrada Fonte Lappone, 86090 Pesche, Italy

15 Department of Botany, University of Innsbruck, Sternwartestr. 15, 6020 Innsbruck, Austria

16 Department of Geo-Information in Environmental Management, Mediterranean Agronomic Institute of Chania, PO Box 85, 73100 Chania, Greece

17 Georgian Institute of Public Affairs, Ietim Gurji St. 7B, 0105 Tbilisi, Georgia

18 Hirzingerweg 23, 6380 St. Johann i. Tirol, Austria
19 Department of Industrial Economics and Technology Management, Norwegian University of Science and Technology, 7491 Trondheim, Norway

20 Institute of Plant and Animal Ecology, Ural Branch of the Russian Academy of Sciences, 8 Marta, 202, 620144 Ekaterinburg, Russia

21 Department of Biological and Environmental Sciences, University of Gothenburg, 40530 Gothenburg, Sweden

22 Environmental Protection Agency of Aosta Valley (ARPA), La Maladière 48, 11020 St-Christophe, Italy

23 Institute of Meteorology and Climatology, University of Natural Resources and Life Sciences, Vienna (BOKU), Gregor-Mendel-Straße 33, 1180 Vienna, Austria

24 Department of Animal Sciences, Institute of Biology, University of Campinas, Campinas, Brazil

25 Norwegian Institute for Nature Research, P.O. box 5685 Torgarden, 7485 Trondheim, Norway

26 A. Borza Botanic Garden, Babeș-Bolyai University, Republicii 42, Cluj-Napoca, Romania

27 Faculty of Biology and Geology, Babeș-Bolyai University, Republicii 44, Cluj-Napoca, Romania

28 DSTA, Department of Earth and Environmental Sciences, Pavia University, Sant'Epifanio 14, 27100 Pavia, Italy

29 EnvixLab, Department of Bioscience and Territory, University of Molise, Via Duca degli Abruzzi, 86039 Termoli, Italy

30 Department of Chemistry, Life Sciences and Environmental Sustainability, University of Parma, Parco Area delle Scienze 11/A, 43124 Parma, Italy

31 Stange 45, 39050 Ratschings, Italy

32 Institute of Biological Research, NIRDBS Bucureşti Branch, Cluj-Napoca, Romania

33 Instituto Pirenaico de Ecología (IPE-CSIC), Av. N. ${ }^{a}$ S. ${ }^{a}$ de la Victoria 12, 22700 Jaca, Huesca, Spain

34 Faculty of Geosciences and Environment, Institute of Earth Surface Dynamics, University of Lausanne, 1015 Lausanne, Switzerland

35 Engineering \& IT, Carinthia University of Applied Sciences, 9524 Villach, Austria 